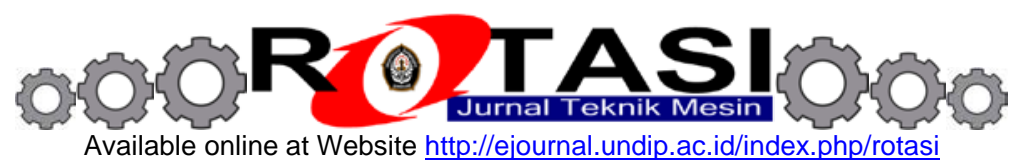

\title{
Karakterisasi Material Biokomposit Bovine Hidroksapatit (BHA)/Shellac dan Kitosan Sebagai Material Bone Filler
}

\author{
Junaidi Rasid, *Joko Triyono, Teguh Triyono \\ Jurusan Teknik Mesin, Fakultas Teknik, Universitas Sebelas Maret \\ Jl. Ir Sutami No 36-A Kentingan Surakarta. Kode Pos, 57126. Telp, (0271) 646994. Fax, (0271) 646655 \\ *e-mail: jokotri5528@gmail.com
}

\begin{abstract}
Abstrak
Development of composite materials is growing rapidly to support medical needs. Biocomposite was made from bovine bone powder/shellac/chitosan for bone filler applications. Biocomposite of BHA(Bovine Hydroxyapatite)/shellac/chitosan was derived of bovine bone powder coated with shellac $10 \mathrm{ml}$. Mixed variation between BHA/shellac and chitosan i.e 30:40, 40:60, 50:50, 60:40, 70:30 \%wt were synthesized by dry method. Samples of BHA/shellac/chitosan were compacted with the pressure 60 bar until becomes solid with the cylinder mold $13 \mathrm{~mm}$ and $8 \mathrm{~mm}$ in thickness, the calcination process on temperature of $900^{\circ} \mathrm{C}$ for 2 hours and increased temperature is $10^{\circ} \mathrm{C} / \mathrm{min}$. Test XRD $(X-$ Ray Diffraction), Microvickers, DTS (Diametric Tensile Strength) and SEM (Scanning Electron Microschopy), Density, and Porosity. XRD test results showed that bovine powder has become BHA (Bovine Hydroxyapatite), microvickers test of sample BHA/shellac/chitosan for maximum was $7.47 \pm$ $0.685 \mathrm{VHN}$ and $0.182 \pm 3.73 \mathrm{VHN}$ for minimum, DTS test of sample BHA/shellac/chitosan maximum at $36.66 \pm 9.01 \mathrm{KPa}$ and minimum at $13.90 \pm 1.24 \mathrm{KPa}$. Porous observations with SEM toward sample $\mathrm{BHA} /$ shellac/chitosan porous size and number of samples contained at BHA/shellac/chitosan is 70:30 wt $\%$. Density test with highest value was $1,168 \mathrm{gr} / \mathrm{cm} 3$, and lowest $1,070 \mathrm{gr} / \mathrm{cm} 3$. Highest porosity value at variation 50/50 \%wt $=0,988 \%$, and the lowest at $70 / 30 \% w t=0,977 \%$.
\end{abstract}

Kata kunci: Hydroxyapatit, kitosan, XRD, Microvickers Diametral Tensile Strength, SEM

\section{Pendahuluan}

Di Indonesia kebutuhan bone graft akan bertambah seiring meningkatnya kasus kerusakan tulang akibat trauma, tumor, kelainan kongenital, infeksi, dan resorbsi tulang akibat komplikasi pemasangan protesa sendi. Jumlah bone graft yang ada tidak dapat memenuhi kebutuhan bone graft yang terus meningkat, sehingga untuk mengatasi masalah ini adalah dengan penggunaan bone graft sintetis, yang salah satu bahan bakunya adalah hidroksiapatit sintetis.

Material pengganti untuk bone graft harus memenuhi kriteria sebagai berikut: (a) struktur berpori dengan luas permukaan yang besar, (b) osteokonduktivitas yang baik sehingga memungkinkan terjadinya interaksi antarmuka yang aktif, (c) kompatibel serta bersifat biodegradasi yang terkontrol, dan (d) memiliki sifat mekanik tertentu [1]. Pori pada tulang berfungsi untuk interaksi antarmuka dan mendukung terjadinya proliferasi sel.

Hidroksiapatit yang disintesis dari bahan alam memiliki osteokonduktivitas yang lebih baik dibandingkan dengan dari bahan sintetik. Aplikasi dan penggunaan HA berukuran partikel untuk perbaikan tulang dan gigi rusak memiliki potensi yang sangat menjanjikan. Penelitian tentang hidroksiapatit (HA) dilapisi oleh lak berasal dari sekresi resin dari hewan serangga lac [2]. Berdasarkan hal tersebut diperlukan penelitian mengenai biokeramik tulang sapi (bovine bone) dengan metode serbuk dengan pengikatnya adalah shellac dan disintesiskan menggunakan kitosan yang digunakan sebagai pembuat porus. Hasil dari penelitian ini diharapkan dapat digunakan sebagai biomaterial baru dan sebagai bone graft untuk perbaikan kerusakan tulang.

\section{Material dan metode}

Pada penelitian ini dilakukan proses pembuatan serbuk dari tulang sapi dengan ukuran $100 \mu \mathrm{m}$ kemudian serbuk tulang sapi direndam dengan shellac selama 24 jam. Shellac digunakan sebagai bahan penguat serbuk tulang sapi. Metode yang dipakai dalam penelitian ini adalah dengan metode kering yaitu serbuk tulang sapi dengan pengikatnya adalah shellac dan disintesiskan menggunakan kitosan. Setelah bahan terkumpul dilakukan proses pencampuran dengan variasi campuran BHA/shellac/kitosan 30:70, 40:60, 50:50, 60:40, 70:30 kemudian dicetak di dalam cetakan berdiameter $13 x 8 \mathrm{~mm}$ dan dikompaksi dengan mesin press dengan penekanan 60 bar selama 5 menit. Spesimen kemudian dikalsinasi pada suhu $900^{\circ}$.

\section{Hasil dan pembahasan}

\subsection{Analisa fasa hidroksapatit dengan XRD (X-Ray Diffraction)}

Analisa ini menunjukkan hasil pengamatan pola difraksi XRD diperoleh dari sampel bovine hidroksapatit (BHA)/shellac dan kitosan. Pola difraksi XRD dari BHA/shellac dan BHA/shellac/kitosan dibandingkan dengan hasil pengamatan pola difraksi XRD dari BHA ditunjukkan pada Gambar 1, 2, dan 3 berikut. 


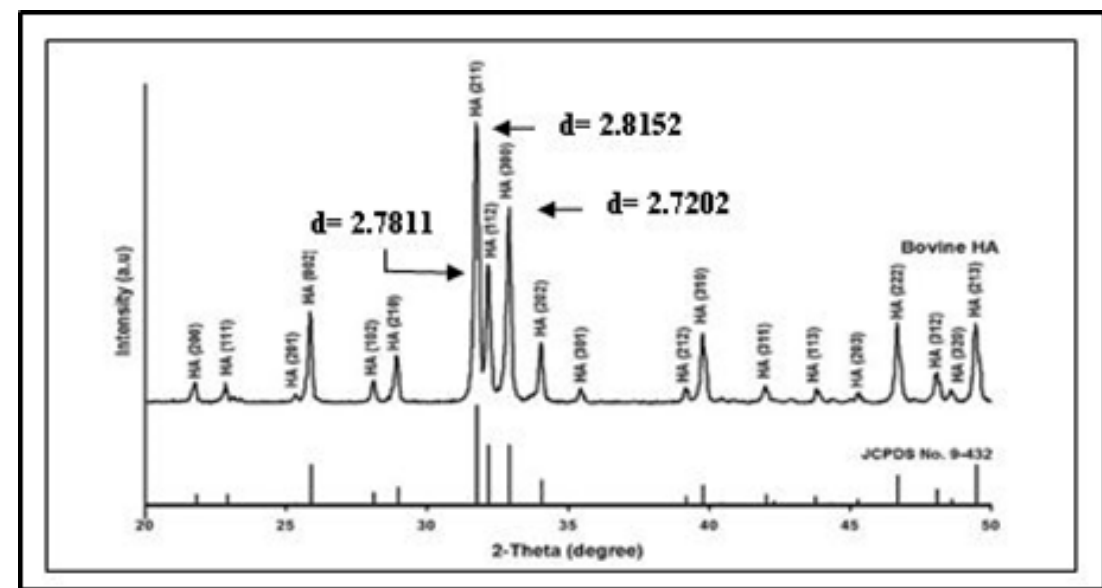

Gambar 1. Pola Difraksi XRD BHA.

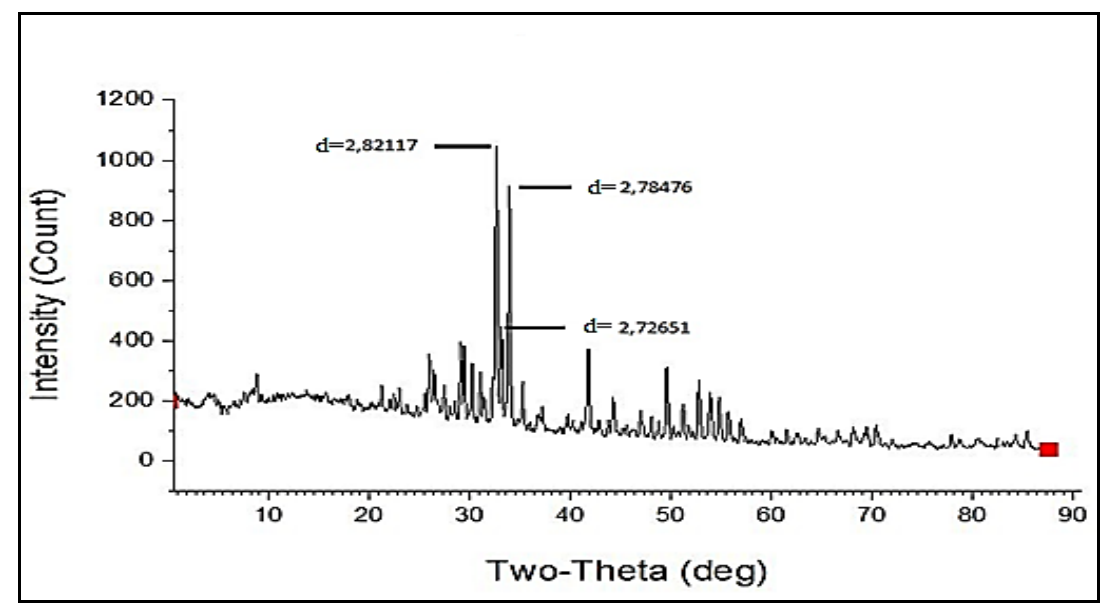

Gambar 2. Pola Difraksi XRD BHA/shellac

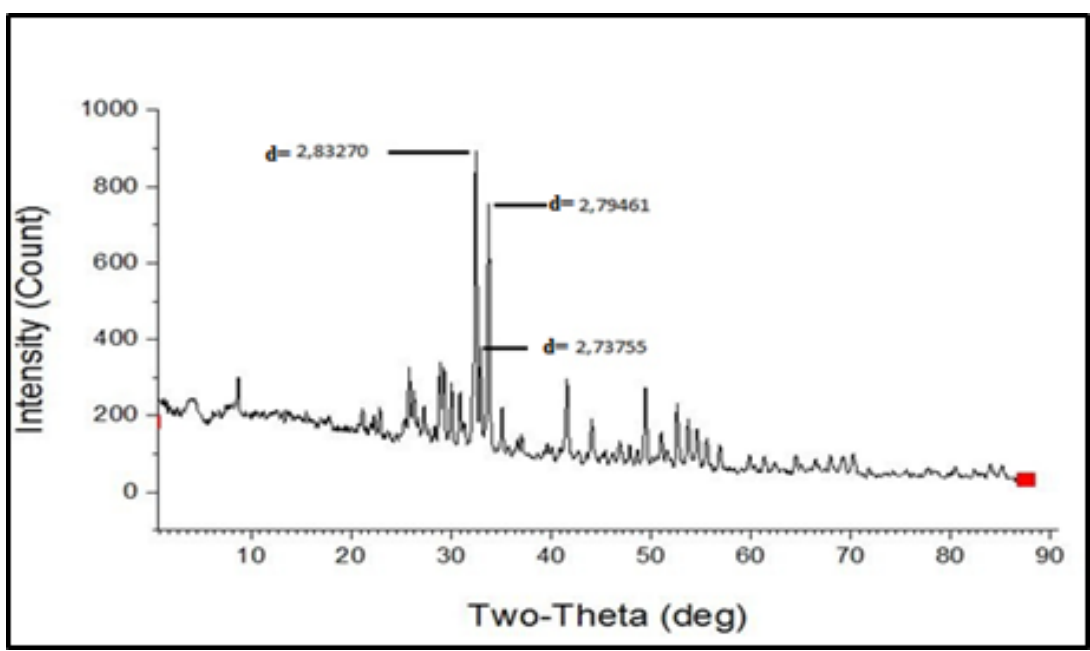

Gambar 3. Pola Difraksi XRD BHA/shellac/kitosan

Hasil pengamatan XRD ditunjukkan dengan 40kV, 30mA, dan $\mathrm{Cu} 1.54060$ A. Pola difraksi BHA/shellac dan kitosan dikonfirmasi dengan pola difraksi BHA/shellac. Pola difraksi BHA/shellac dan kitosan menghasilkan pola difraksi dengan intensitas tinggi pada nilai $2 \theta$ : $31.5585^{\circ}, 32.6855^{\circ}, 32.0001^{\circ}$. Nilai $2 \theta$ untuk senyawa HA (hidroksapatit) sesuai dengan pola difraksi standar. Pola difraksi dari BHA/shellac yakni nilai 20: $31.6908^{\circ}, 32.8216^{\circ}$, $32.1163^{\circ}$. Dengan perbandingan pola difraksi (BHA)/shellac dan kitosan dan BHA/shellac yang memiliki nilai pola difraksi hampir sama, maka bisa dikatakan BHA/shellac dan kitosan telah menjadi hidroksapatit. Hasil XRD dari BHA menurut [3] yang ditunjukkan dengan pola difraksi dengan pola intensitas tinggi pada nilai $2 \theta: 21.760^{\circ}, 22.840^{\circ}$, $25.320^{\circ}$. 


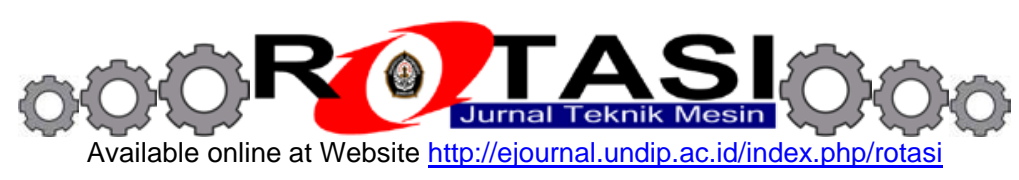

\subsection{Analisa uji kekerasan Vickers (Vickers Hardness Tester)}

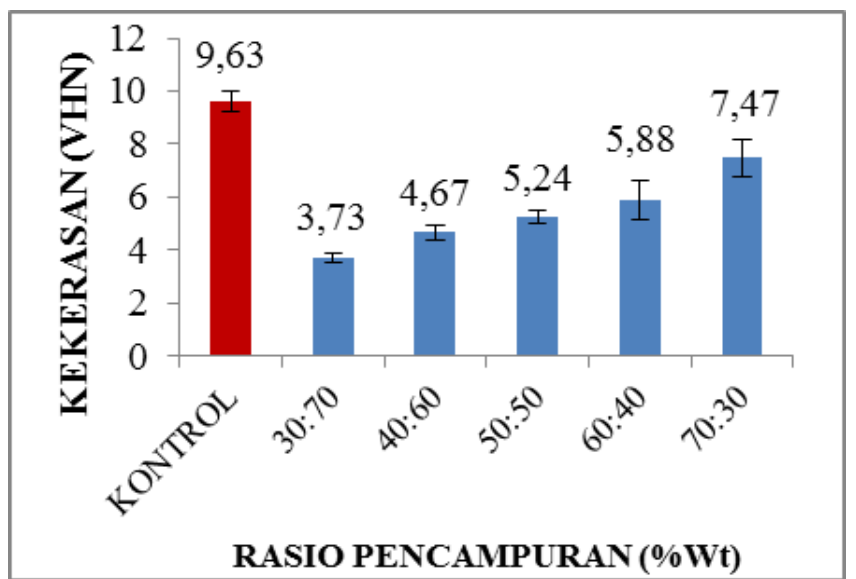

Gambar 4 nilai kekerasan microvickers BHA/shellac dan kitosan setelah kalsinasi.

Hasil uji kekerasan menunjukkan peningkatan jumlah kitosan pada sampel BHA/shellac/kitosan mengakibatkan kekerasan sampel cenderung menurun. Hal tersebut dikarenakan kitosan yang digunakan sebagai pembentuk porus yang memiliki titik lebur lebih rendah dari BHA, serta dengan semakin banyak bahan pembuat porus semakin sedikit ikatan antar serbuk tulang. Sampel uji BHA/shellac (kontrol) memiliki nilai kekerasan 9,63 VHN. Nilai kekerasan paling terendah sampel variasi campuran BHA/shellac/kitosan 3,73 VHN pada variasi campuran 30:70. Terjadi peningkatan nilai VHN pada sampel 70:30 sekaligus menjadi nilai kekerasan paling maksimum sampel BHA/shellac/kitosan yakni 7.47 VHN. Hal tersebut dipengaruhi oleh campuran shellac untuk BHA/kitosan, sehingga menyebabkan nilai kekerasan sampel BHA/shellac/kitosan meningkat. Hal ini diperkuat dengan penelitian dari [3] yang melaporkan bahwa nilai kekerasan paling optimal yakni $2.403 \mathrm{VHN}$ (suhu $1300^{\circ} \mathrm{C}$ ) dan nilai terendah yakni 1.346 VHN (suhu $1400^{\circ} \mathrm{C}$ ). Dari referensi diatas bahwa suhu kalsinasi mempengaruhi dari kekerasan HA. Teh, dkk (2014) melaporkan bahwa nilai kekerasan paling tinggi HA kalsinasi yakni 7.23 VHN (tanpa kalsinasi dan suhu sinter $1150^{\circ} \mathrm{C}$ ), nilai kekerasan terendah yakni 1,65 VHN (suhu kalsinasi $1000^{\circ} \mathrm{C}$ dan suhu sinter $1050^{\circ} \mathrm{C}$ ). Dapat disimpulkan bahwa suhu mempengaruhi dari nilai kekerasan dari material BHA.

\subsection{Analisa uji kuat tekan}

Dari pengujian spesimen berbentuk tablet BHA/shellac dan kitosan setelah kalsinasi pada suhu $900^{\circ} \mathrm{C}$ selama 2 jam dengan kenaikan suhu $10^{\circ} \mathrm{C} /$ menit menggunakan uji diametral tensile strength (DTS) menggunakan Universal Testing Machine (JTM Technology Machine, 0.5T Capacity) dengan load 50kg dengan kecepatan penekanan $5 \mathrm{~mm} /$ menit. Hasil pengujian Diametral Tensile Strength (DTS) ditunjukkan Gambar 5 berikut.

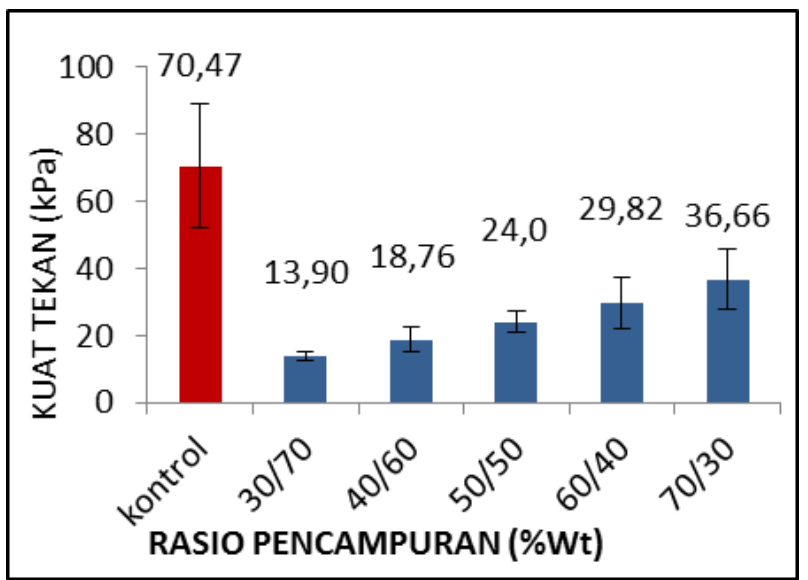

Gambar 5. Grafik perbandingan kuat tekan pada variasi rasio pencampuran BHA/shellac dan kitosan.

Dari data Gambar 5 dapat diketahui bahwa kekuatan tekan dari spesimen tablet BHA/shellac dan BHA/shellac dan kitosan mengalami kenaikan dari variasi 30:70 hingga 70:30 dengan nilai kuat tekan tertinggi sebesar 36,66 KPa. Pada variasi pencampuran 70:30 didapat hasil kuat tekan yang terbaik dengan 36,66 KPa dan hasil kuat tekan yang terendah ada pada variasi 30:70 dengan 13,90 KPa. Variasi 70:30 jumlah BHA/shellac lebih banyak daripada kitosan dan variasi 50:50 jumlah BHA/shellac jumlah bahan pembuat porus seimbang. Tujuan ditambahkan kitosan adalah 
untuk membuat porus pada spesimen. Pada variasi 30:70 hasil kuat tekan terendah yaitu 13,90 KPa. Variasi 60:40 jumlah BHA/shellac lebih banyak daripada kitosan sehingga membuat keporusannya berkurang tetapi kuat tekannya meningkat yaitu 29,82 KPa. Variasi 70:30 jumlah BHA/shellac jauh lebih banyak dari kitosan membuat keporusan spesimen berkurang mendapatkan hasil kuat tekan yang tertinggi yaitu 36,66 KPa. Hasil uji kuat tekan BHA/shellac ternyata jauh berada dibawah variasi BHA/shellac/kitosan. Dari hasil kuat tekan tersebut dapat dilihat bahwa campuran BHA/shellac/kitosan memiliki kuat tekan lebih tinggi.

Hal ini diperkuat dengan hasil penelitian yang menyatakan bahwa, nilai kuat tekan (DTS) HA komersil tanpa penambahan zirconia (0\%wt) yakni 4.956 $\pm 0.504 \mathrm{MPa}$, nilai kuat tekan (DTS) maksimal HA komersil dengan penambahan zirconia 40\%wt yakni 7.766 MPa. [4] Serupa dengan [4], [2] menyatakan bahwa penambahan shellac terhadap BHA dapat menaikkan nilai kuat tekan setelah kalsinasi pada suhu $1200^{\circ} \mathrm{C}$ selama 2 jam. Nilai kuat tekan optimum dari BHA/shellac yakni 5.2 MPa pada komposisi 10\% penambahan shellac, untuk nilai kuat tekan minimum dari BHA/shellac yakni 3.2 MPa pada komposisi 2.5\% penambahan shellac.

\subsection{Pengamatan Scanning Electron Microschopy (SEM)}

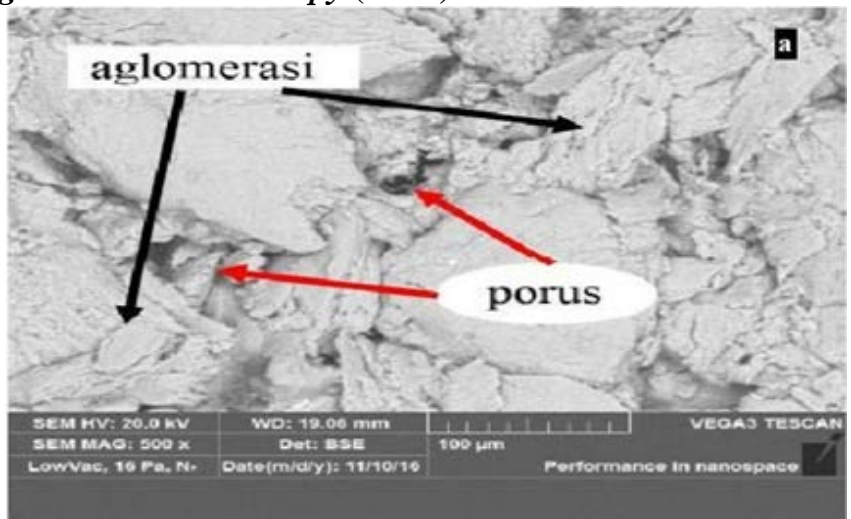

Gambar 6. BHA/shellac/tepung 50:50.

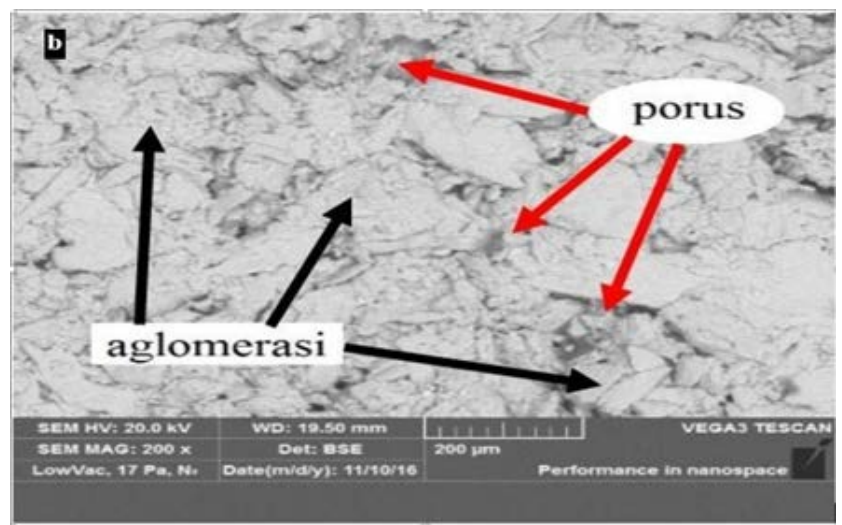

Gambar 7. BHA/shellac/tepung 60:40.

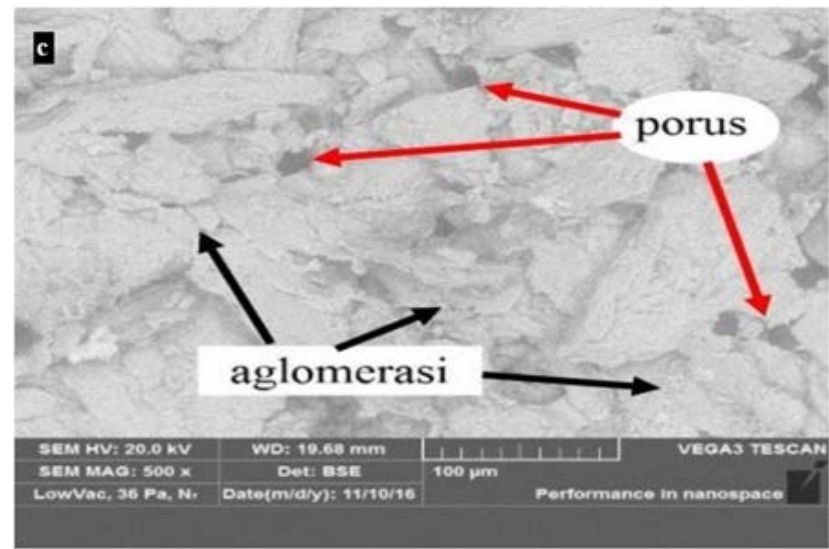

Gambar 8. BHA/shellac/tepung 70:30. 


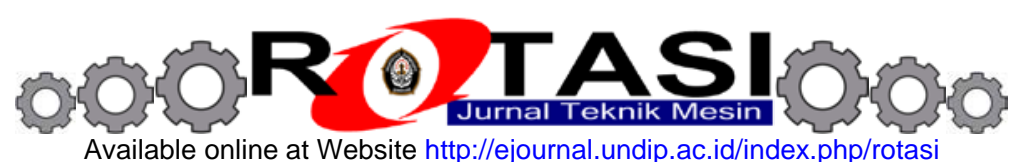

Dari Gambar 6, 7, dan 8 dapat dijelaskan tentang porus dan aglomerasi (gumpalan) yang terjadi pada sampel tablet BHA/shellac/kitosan dengan perbandingan 50:50, 60:40, dan 70:30 \% Wt. Pada sampel yang diamati telah terjadi porus dan gumpalan. Gumpalan HA terbentuk setelah kalsinasi BHA/shellac. Terbentuknya porus disebabkan oleh kitosan yang menghilang selama proses kalsinasi. Hal ini disebabkan kitosan yang bertujuan sebagai bahan porogen memiliki titik lebur yang rendah. Titik lebur kitosan adalah $215^{\circ} \mathrm{C}$ [5].

Pada Gambar 6 sampel perbandingan 50:50 porus yang terjadi tidak beraturan dan tidak merata. Pada gambar 7 dan 8 porus yang terjadi juga tidak beraturan ukuran dari porus pada perbandingan ini semakin membesar. Porus yang terjadi pada spesimen sebarannya tidak merata. Porus yang terdapat pada sampel tidak beraturan, hal ini dipengaruhi oleh kuantitas dari kitosan, yang juga mempengaruhi jumlah porus dan ukuran porus. Hal ini sebanding dengan hasil pengujian porositas bahwa porositas yang terbentuk semakin tinggi seiiring dengan bertambahnya \%wt kitosan. Kemudian diperkuat pula dengan hasil penelitian yang menyatakan bahwa pada suhu yang lebih tinggi, partikel serbuk telah menyatu dan membentuk ikatan-ikatan serbuk yang lebih baik dan memiliki struktur mikro yang kasar [6].

\subsection{Pengujian densitas dan porositas}

Pengujian densitas dilakukan untuk mengetahui perbandingan antara densitas aktual dan densitas teoritis menurut rule of mixture. Hasil pengujian densitas sering digunakan untuk memprediksi berbagai fenomena yang terjadi, seperti memprediksi kekuatan material. Berikut nilai densitas aktual dari BHA/shellac/kitosan ditunjukkan Gambar 9.

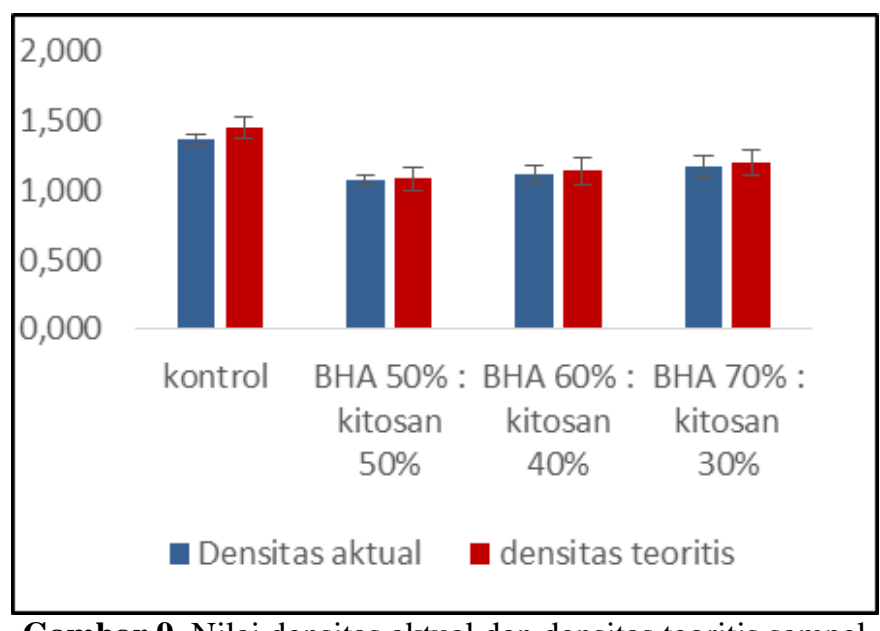

Gambar 9. Nilai densitas aktual dan densitas teoritis sampel

Pengujian nilai densitas aktual BHA/shellac dan kitosan menggunakan air sebagai media fluida nya. Pada Gambar 4.10 menunjukkan peningkatan densitas aktual untuk semua campuran. Pada densitas aktual sampel kontrol memiliki nilai densitas aktual rata-rata sebesar $1.366 \mathrm{gr} / \mathrm{cm} 3$. Nilai densitas aktual sampel 50:50 memiliki nilai rata-rata sebesar $1.070 \mathrm{gr} / \mathrm{cm} 3$. Nilai densitas aktual sampel 60:40 memiliki nilai rata-rata sebesar $1.118 \mathrm{gr} / \mathrm{cm} 3$, sedangkan nilai densitas aktual sampel 70:30 memiliki nilai rata-rata sebesar 1,168 gr/cm3. Sedangkan nilai densitas teoritis yakni 1.450 gr/cm3 (kontrol), 1.083 gr/cm3 ( 50:50), 1.140 gr/cm3 (60:40), dan 1.196 gr/cm3 (70:30). Nilai densitas aktual sampel BHA/shellac dan kitosan dipengaruhi oleh \%wt BHA/shellac dan \%wt kitosan. Hal ini diperkuat dengan penelitian yang menyatakan bahwa semakin bertambahnya \% wt HA, maka nilai densitas nya semakin naik [7][8]

Pengujian porositas digunakan untuk menghitung celah/rongga kosong yang berisi udara atau gas. Nilai porositas didapat dari perhitungan densitas aktual dan teoritik. Nilai porositas BHA/shellac dan kitosan ditunjukkan pada Gambar 10 Grafik hubungan porositas dengan variasi campuran.

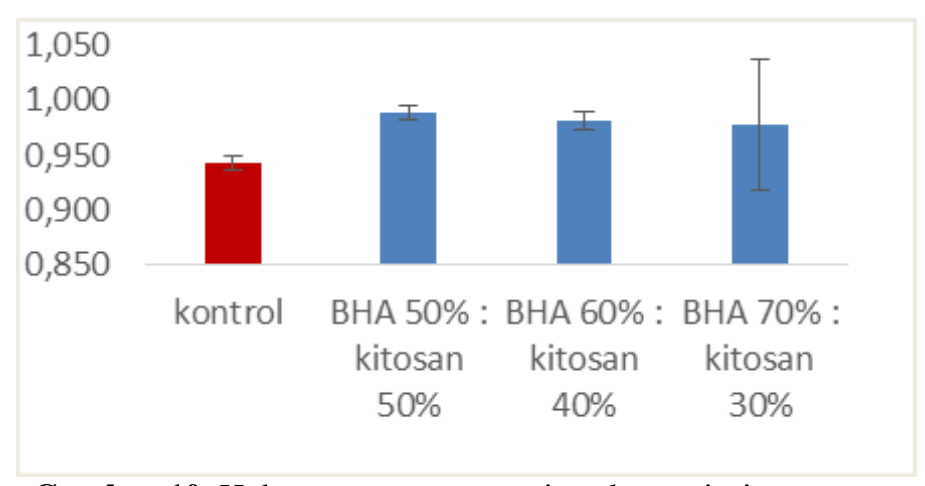

Gambar 10. Hubungan antara porositas dan variasi campuran 
Dari hasil perhitungan porositas BHA/shellac dan kitosan dengan variasi campuran menunjukkan bahwa porositas yang terbentuk semakin tinggi seiring dengan bertambahnya \%wt kitosan. Tingkat porositas yang tinggi disebabkan efek kalsinasi yang mengakibatkan BHA/shellac dan kitosan terdapat ruang/lubang yang berisi udara. Gambar 10 memperlihatkan nilai porositas terendah yakni 0.988\% (70:30), dibandingkan pada variasi 60:40 dan 50:50 sebesar $0.981 \%$ dan $0.977 \%$. Terbentuknya porositas disebabkan oleh perbedaan suhu melting point dari material [9]. Material yang digunakan adalah BHA yang memiliki melting point $1670^{\circ} \mathrm{C}$, kitosan $=215^{\circ} \mathrm{C}[5]$ dan shellac $=105^{\circ} \mathrm{C}$. Dari sampel yang telah dikalinasi pada $900^{\circ} \mathrm{C}$ terjadi porositas akibat melting point dari kitosan dan shellac yang lebih rendah dari BHA. Hal ini diperkuat dengan penelitian yang menyatakan bahwa nilai porositas dari HA-zirconia semakin menurun seiring dengan bertambahnya \% wt zirconia, sedangkan nilai kekuatan tekan semakin meningkat [4][10]

Dalam penelitian bovine hidroksiapatit (BHA)/shellac dan kitosan setelah kalsinasi $900^{\circ} \mathrm{C}$ selama 2 jam dengan kenaikan $10^{\circ} \mathrm{C} /$ menit, semakin tinggi \% wt BHA maka nilai kekerasan dan kuat tekan meningkat. Semakin tinggi \%wt kitosan, maka porogen yang terbentuk semakin nampak. Hal ini sesuai dengan pengujian densitas aktual dan porositas yang menyebabkan terbentuknya lubang (porus) setelah sampel di kalsinasi. Hal ini diperkuat dengan pengamatan SEM yang menjelaskan bahwa porogen yang terbentuk setelah sintering pada BHA/shellac dan kitosan.

\section{Kesimpulan}

Berdasarkan proses pengujian, pengamatan serta hasil dari pembahasan yang telah dilakukan dalam penelitian dapat diambil kesimpulan sebagai berikut:

1. Uji X-Ray Diffraction (XRD) menunjukkan BHA/shellac/kitosan telah menjadi BHA.

2. Nilai kekerasan BHA/shellac/kitosan tertinggi yakni 7.47 VHN pada perbandingan 70:30, kemudian nilai kekerasan BHA/shellac/kitosan paling terendah yakni 3,73 VHN.

3. Nilai kuat tekan BHA/shellac/kitosan tertinggi yakni 36,66 KPa, kemudian nilai kuat tekan $\mathrm{BHA} /$ shellac/kitosan paling terendah yakni 13,90 KPa.

4. Pengamatan SEM dari sample telah menunjukan terjadi porus, jumlah \%wt kitosan sebagai bahan pembuat porus mempengaruhi nilai kekerasan, nilai kuat tekan, densitas, dan porositas.

\section{Referensi}

[1] Wang, Q., Yan, J., Yang, J., and Li, B., 2016, Nanomaterials Promise Better Bone Repair, Materials Today, Vol. 19 (8), pp. 451-463.

[2] Triyono, J., Susmartini, S., Susilowati, E., and Murdiyantara, S.A., 2015, Shellac Coated Hydroxyapatite (Ha) Scaffold for Increasing Compression Strength, Advanced Materials Research.

[3] Herliansyah, M., Hamdi, M., Ide-Ektessabi, A., Wildan, M., and Toque, J., 2009, The Influence of Sintering Temperature on the Properties of Compacted Bovine Hydroxyapatite, Materials Science and Engineering: C, Vol. 29 (5), pp. 1674-1680.

[4] Pujiyanto, E., and Widyo Laksono, P., 2015, Sintering Behavior and Diametral Tensile Strength Properties of Hydroxyapatite-Zirconia Composites, Materials Science Forum.

[5] Drebushchak1, V., Shakhtshneider, T., Apenina, S., Drebushchak, T., Medvedeva, A., Safronova, L., et al., 2006, Thermoanalytical Investigation of Drug-Excipient Interaction: Part I. Piroxicam, Cellulose and Chitosan as Starting Materials, Journal of thermal analysis and calorimetry, Vol. 84 (3), pp. 643-649.

[6] Teh, Y., Tan, C., Ramesh, S., Purbolaksono, J., Tan, Y., Chandran, H., et al., 2014, Effect of Calcination on the Sintering Behaviour of Hydroxyapatite, Ceramics-Silikáty, Vol. 58 (4), pp. 320-325.

[7] Khan, M., Ghoshal, S., Khan, R., Pervin, S.-A., and Mustafa, A., 2008, Preparation and Characterization of Jute Fiber Reinforced Shellac Biocomposites: Effect of Additive.

[8] Sedyono, J., Tontowi, A., and Ana, I., 2007, Fabrikasi Dan Karakterisasi Xrd Hidroksiapatit Dari Gipsum Alam Kulon Progo.

[9] Tontowi, A.E., Dewo, P., Wahyuni, E.T., and Triyono, J., 2012, Scaffold Dari Bovine Hydroxyapatite Dengan Poly Vynialchohol Coating, Jurnal Teknosains, Vol. 1 (2).

[10] Chen, Y., Dong, Z., and Miao, X., 2009, The Effect of Yttria-Stabilized Zirconia on the Properties of the Fluorine-Substituted Hydroxyapatite Ceramics Prepared by Pressureless Sintering, Journal of Biomimetics, Biomaterials and Tissue Engineering. 